\title{
Passage Performance of Technical Pool-Type Fishways for Potamodromous Cyprinids: Novel Experiences in Semiarid Environments
}

\author{
Francisco Javier Sanz-Ronda ${ }^{1, *} *$, Francisco Javier Bravo-Córdoba ${ }^{1} \oplus$, Ana Sánchez-Pérez ${ }^{2}$, \\ Ana García-Vega ${ }^{1}{ }^{\infty}$, Jorge Valbuena-Castro ${ }^{1}$, Leandro Fernandes-Celestino ${ }^{3}{ }^{\circledR}$, Mar Torralva ${ }^{2}$ \\ and Francisco José Oliva-Paterna ${ }^{2}$ (i) \\ 1 Applied Ecohydraulics Group (GEA-ecohidraulica.org), E.T.S.II.AA, University of Valladolid, 34004 Palencia, \\ Spain; francisco.bravo@iaf.uva.es (F.J.B.-C.); ana.garcia.vega@iaf.uva.es (A.G.-V.); \\ jorge.valbuena@uva.es (J.V.-C.) \\ 2 Departmento of. Zoology and Physical Anthropology, Universityof Murcia, 30100 Murcia, Spain; \\ ana.sanchez15@um.es (A.S.-P.); torralva@um.es (M.T.); fjoliva@um.es (F.J.O.-P.) \\ 3 Group on Technology in Ecohydraulics and Conservation of Fishery and Water Resources (GETECH), \\ Western Paraná State University (Unioeste), 85903 Toledo, Brazil; le_celestino@hotmail.com \\ * Correspondence: jsanz@iaf.uva.es or escalasparapeces@gmail.com
}

Received: 22 October 2019; Accepted: 8 November 2019; Published: 11 November 2019

\begin{abstract}
Endemic freshwater fish from semiarid environments are among the most threated species in the world due to water overexploitation and habitat fragmentation problems. Stepped or pool-type fishways are used worldwide to reestablish longitudinal connectivity and mitigate fish migration problems. Many of them are being installed or planned in rivers of semiarid environments, however, very few studies about fish passage performance through pool-type fishways has been carried out to date on these regions. The present work focuses on the passage performance of two potamodromous cyprinids endemic of these regions, with different ecological and swimming behavior: southern Iberian barbel (Luciobarbus sclateri) and Iberian straight-mouth nase (Pseudochondrostoma polylepis). These are assessed in two of the most common types of stepped fishways: vertical slot and submerged notch with bottom orifice fishways. Experiments were carried out during the spawning season in the Segura River (southeastern Spain), using a passive integrated transponder (PIT) tag and antenna system. Ascent success was greater than $80 \%$, with a median transit time lower than 17 minutes per meter of height in all trials, and for both species and fishway types. Results show that both types of fishways, if correctly designed and constructed, provide interesting alternatives for the restoration of fish migration pathways in these regions.
\end{abstract}

Keywords: Mediterranean region; river connectivity; fishway assessment; fish motivation; ascent ability

\section{Introduction}

Rivers in semiarid environments are subjected to strong seasonal variability-long drought periods alternated with large but brief floods [1,2]. Thus, water resources are strongly exploited, and rivers are highly affected by barriers and flow regulation [3,4]. Transverse barriers, such as dams, weirs, and gauging stations, and the involved habitat fragmentation are considered the main threats to ichthyofauna worldwide [5,6], including in semiarid regions [7-9]. Moreover, near-future scenarios suggest more water demand and the exacerbation of human stressors [10,11]. In these areas (i.e., from the circum-Mediterranean region to Central Asia), freshwater fish fauna present a high degree of endemism and are characterized by a low number of families, with most of the species belonging to the Cyprinidae family [12-15]. The most abundant species are barbels (genus Barbus and 
Luciobarbus) and nases (genus Chondrostoma, Pseudochondrostoma, and Parachondrostoma). Both rheophilic potamodromous cyprinids are under different levels of threat according to the International Union for Conservation of Nature (IUCN) Red List of Threatened Species $[4,16]$. This ichthyofaunistic group is an important link for the trophic interactions within the ecosystem and inhabits the entire length of the river, migrating during the spring in order to reproduce in shallow waters with gravel and moderate current velocity $[13,17]$. Two representative potamodromous fish species of the Iberian semiarid region are the Southern Iberian barbel (Luciobarbus sclateri) and the Iberian straight-mouth nase (Pseudochondrostoma polylepys) [18]. Both species are common in the southern and eastern Iberian Peninsula and they show different ecological traits and swimming behavior [19]. The Southern Iberian barbel is defined as a sentinel species [20] in this region, and it is a large-bodied benthic fish that lives in slow water velocity habitats. Iberian straight-mouth nase is a medium-bodied water column fish that inhabits running waters [16].

River connectivity is an essential requirement for the effective functioning of freshwater ecosystems, and in particular for allowing fish to complete their life cycles [21,22]. The longitudinal connectivity for fish is usually restored by different types of fishways. Technical pool-type or stepped fishways are the most used designs around the world [23,24], including in semiarid regions [25-28]. Nevertheless, in northern Africa, the Eastern Mediterranean area, and Central Asia, fishways in cyprinid rivers are still very scarce [29-31]. These types of fishways consist of pools connected by cross-walls with slots, notches, and/or orifices, which divide the total height of an obstacle into smaller drops to ensure that the hydraulic conditions inside are in the range of the physical capacities of fish fauna, and thus, enable their passage [32,33]. The most common designs in the Iberian Peninsula are vertical slot (VS) and submerged notch with bottom orifice (SNBO) fishways [26,34].

On one hand, VS fishways allow fish movements at any desired depth through the slot and they tolerate variations in the upstream water levels better than $\mathrm{SNBO}$, although they need more discharge than SNBO to get the same depth. In the other hand, SNBO can work with greater slopes and a wider range of design discharge, and they always ensure a minimum depth in the pool. In SNBO, the bottom orifice allows benthic fish passage, although it can be easily clogged by debris [24,32].

The suitability of both VS and SNBO has been previously probed for North American and Central European cyprinids [35], and even for some northern Iberian cyprinids, such as Iberian barbel (Luciobarbus bocagei) and northern straight-mouth nase (Psudochondrostoma duriense) [36-38]. Similar ascension and swimming behaviors are usually assumed for other species of the same genus or family, and thus fishway design criteria of one region are usually extrapolated to other river basins [24,39-41]. Nevertheless, species have evolved by adapting to different hydraulic regimens and climate conditions. Semiarid South Iberian rivers are usually more unsteady and warmer than northern ones. Fishways assessments in this region are still scarce. Hence, studying passage performance of southern fish species will provide important information about their ascent abilities, and in general will improve fishway design.

Passage performance depends on the interactions between physical (geometric and hydraulic features of the fishway), biological (fish behavior, swimming ability, age, sex, physiological status), and environmental (water temperature, fishway discharge) parameters [42-45]. Standardized passage metrics based on movement theory usually consider fish ascent success, transit time, and motivation (definitions in Section 2.4) to quantify passage performance [46-48], and also to compare different types of fishways or to understand the swimming behavior of different fish species [36,38,49].

The present study focuses on the passage performance of two potamodromous cyprinids from a semiarid region of the Iberian Peninsula, Southern Iberian barbel and Iberian straight-mouth nase, in the two main typologies of pool-type fishways: VS and SNBO. Specifically, ascent success, passage time, and motivation of target fish are analyzed to determine: (1) if both types of fishways are suitable for them; (2) if there are differences in passage efficiency between fishway types and fish species; and (3) to understand the influence of hydraulic and biometric parameters on ascent metrics. This information 
will help biologists and engineers in fishway design, implementation, and management decisions in many semiarid watercourses inhabited by species with similar behavior.

\section{Materials and Methods}

\subsection{Study Area and Experimental Sites}

The Segura Basin, in the southeast of Spain, is one of the most arid European regions, with an average annual temperature of $18{ }^{\circ} \mathrm{C}$, scarce rainfall (approximately $300 \mathrm{~mm} /$ year), and intense surface and groundwater overexploitation for irrigation [50]. The experiments were carried out in two fishways located in the middle part of the Segura River: VS in the El Jarral weir (Universal Transverse Mercator -UTM-Grid Zone 30 North; European Terrestrial Reference System 1989 -ETRS 89-, X: 640577, Y: 4229308; Abarán, Murcia) and SNBO in the post-trasvase weir (UTM30 ETRS 89, X: 613788, Y: 4235661; Calasparra, Murcia) (Figure 1). Both fishways are placed in small weirs for combined irrigation and hydropower production. The distance between them is $44.7 \mathrm{~km}$ and they share similar environmental characteristics (flow discharge, substrate, vegetation, and fish population). In the study reach, the Segura River has a catchment area of $8486 \mathrm{~km}^{2}$, with a mean altitude of about $200 \mathrm{~m}$ above mean sea level, and a mean annual discharge of $20.35 \mathrm{~m}^{3} / \mathrm{s}$. It is placed in the Epipotamon zone [51], and corresponds to E4 category: gravel bed stream of high sinuosity with a slope of $0.001-0.02 \mathrm{~m} / \mathrm{m}$ [52]. The fish community in the main stem of the Segura River is very altered due to the modification of the hydrological regime for irrigation and the introduction of non-native invasive species [53]. In the middle part of the basin, among the most abundant potamodromous migratory species are the native southern Iberian barbel and the translocated Iberian straight-mouth nase (hereafter referred to as barbel and nase, respectively) [53].

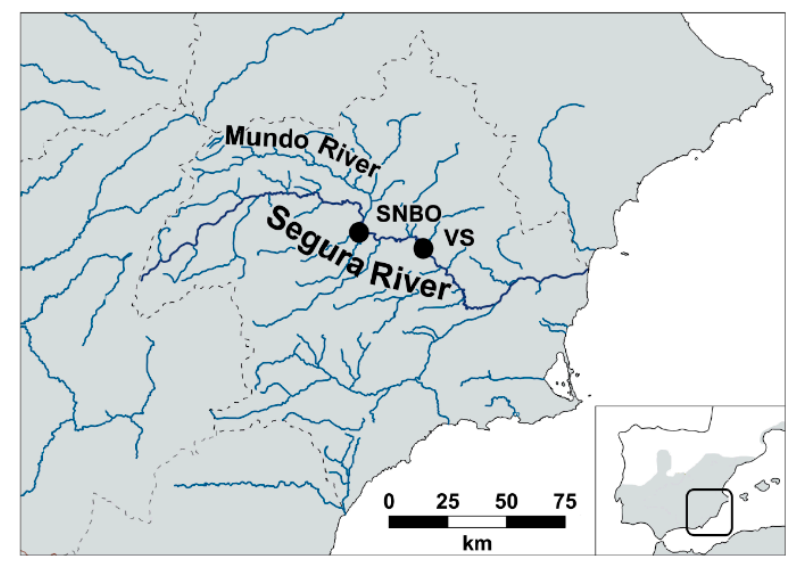

Figure 1. Study site location: Segura River basin in the semiarid region of the western circum-Mediterranean Area.

Both fishways were designed and constructed as a part of the Segura-Riverlink LIFE12 ENV/ES/001140 project [54], following the standard design guidelines [24,32] and considering the geometrical and hydraulic recommendations for cyprinids (Figure 2 and Table 1). Fishway bottoms were covered by substrates from the riverbed to increase roughness, and discharge can be regulated by a sluice gate located in the flow entrance. At each fishway, a section with a $1.80 \mathrm{~m}$ head (difference between the headwater and tailwater levels) was selected for the trials. 


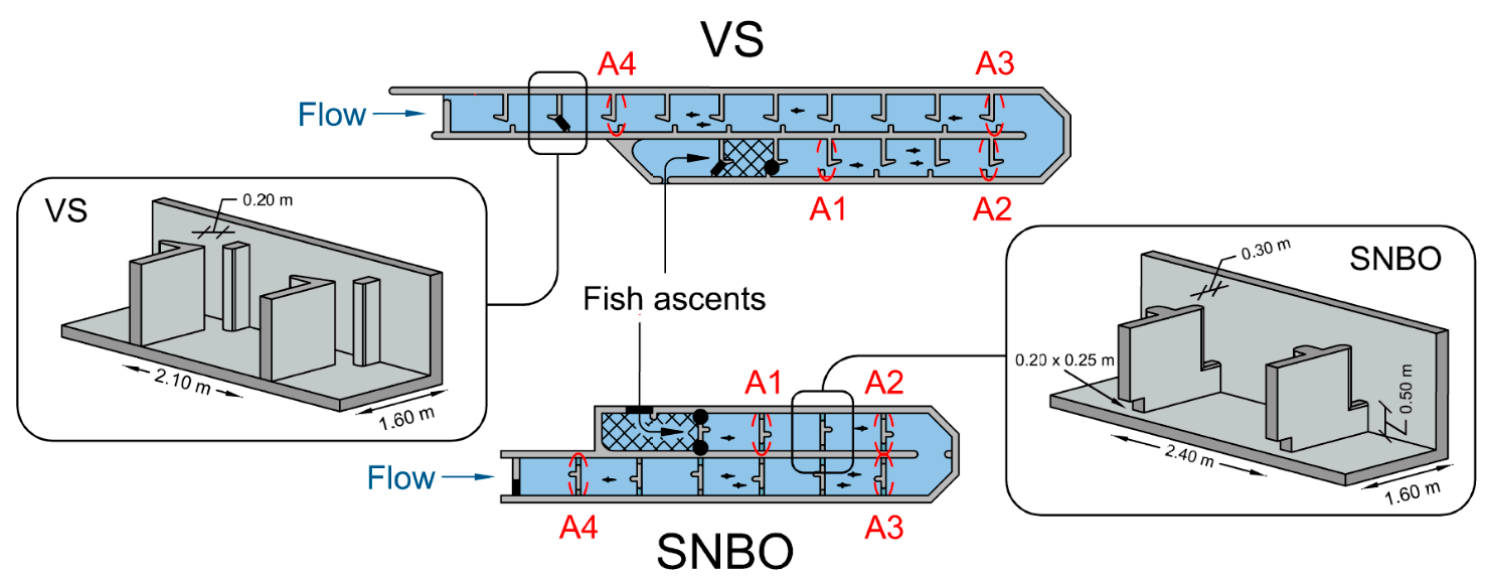

Figure 2. Experimental set-up. Black cross-walls: closing mesh (start and finish of the test section); black circles: closing mesh during adaptation period; mesh over the pools: adaptation pools; dotted circles: antennas with their position number (antenna 1 -A1-, antenna 2 -A2-, etc., being $1.80 \mathrm{~m}$, the relative height between $\mathrm{A} 1$ and $\mathrm{A} 4$ for both fishways); arrows indicate flow and fish ascent directions. Note: $\mathrm{SNBO}=$ submerged notch with bottom orifice; VS = vertical slot.

Table 1. Mean geometric and hydraulic variables for the studied vertical slot (VS) and submerged notch with bottom orifice (SNBO) fishways. Range of values in brackets.

\begin{tabular}{|c|c|c|}
\hline Variables & VS & SNBO \\
\hline Pool dimension (length $\times$ width) & $2.10 \mathrm{~m} \times 1.60 \mathrm{~m}$ & $2.40 \mathrm{~m} \times 1.60 \mathrm{~m}$ \\
\hline Slope & $6.52 \%$ & $7.31 \%$ \\
\hline Number of pools between A1 and A4 & 11 & 8 \\
\hline Width of the slot/notch ${ }^{1}$ & $0.23 \mathrm{~m}(0.20-0.23)$ & $0.32 \mathrm{~m}(0.31-0.36)$ \\
\hline Height of the notch sill ${ }^{1}$ & NA & $0.49 \mathrm{~m}(0.45-0.52)$ \\
\hline Bottom orifice size (length $\times$ width) & NA & $0.20 \mathrm{~m} \times 0.25 \mathrm{~m}$ \\
\hline Drop between pools ${ }^{1}$ & $0.15 \mathrm{~m}(0.14-0.19)$ & $0.19 \mathrm{~m}(0.13-0.24)$ \\
\hline Mean water depth ${ }^{1}$ & $0.91 \mathrm{~m}$ & $0.99 \mathrm{~m}$ \\
\hline Flow discharge 2 & $0.29 \mathrm{~m}^{3} / \mathrm{s}$ & $0.31 \mathrm{~m}^{3} / \mathrm{s}$ \\
\hline Volumetric Energy Dissipation & $118 \mathrm{~W} / \mathrm{m}^{3}(110-149)$ & $148 \mathrm{~W} / \mathrm{m}^{3}(102-181)$ \\
\hline Water velocity at the slot $/$ notch $^{3}$ & $1.38 \mathrm{~m} / \mathrm{s}(1.10-1.47)$ & $1.24 \mathrm{~m} / \mathrm{s}(0.80-1.36)$ \\
\hline Water velocity at the orifice 3 & NA & $1.72 \mathrm{~m} / \mathrm{s}(1.42-1.93)$ \\
\hline
\end{tabular}

\footnotetext{
${ }_{1}^{1}$ Measured with a total station (model Leica TC307, Heerbrugg, Switzerland) or measuring tape $\pm 0.01 \mathrm{~m}$; ${ }^{2}$ Calculated with in the same manner as Fuentes-Pérez et al. [33]; ${ }^{3}$ Direct measurements with a propeller flowmeter $\pm 0.01 \mathrm{~m} / \mathrm{s}$ (model 2100, Swoffer Instruments Inc., Summer, WA, USA). Note: NA = not applicable.
}

The boundary conditions imposed by the river at the entrance of the fishway (water level downstream) during the trials influenced the lower part of the fishway, producing non-uniform conditions with backwater profiles (more evident in the SNBO), increasing the water depth in the most downstream pools and reducing the water drops, and thus obtaining lower values of water velocity and energy dissipation $[33,55]$.

\subsection{Fish Capture, Tagging, and Handling}

A passive integrated transponder (PIT) tag and antenna system was used to study fish movements. Trials were performed from 3-8 May 2017, within barbel and nase reproductive migration periods. Fish were captured by electrofishing (Erreka model; $2000 \mathrm{~W}, 200-250 \mathrm{~V}$, and 2-3 A) one day before trials in river reaches upstream of each fishway. There were unpassable barriers between the capture areas and the experimental fishways. Once captured, fish were anesthetized with tricaine methanesulfonate (MS-222, $0.1 \mathrm{~g} / \mathrm{L}$ ), measured (fork length, $\pm 0.1 \mathrm{~cm}$ ), weighed $( \pm 1 \mathrm{~g}$ ), and tagged with a PIT tag (Table 2). A PIT tag is an encapsulated microchip used for radiofrequency identification (RFID). PIT tags were introduced into the intraperitoneal cavity of the fish through an incision posterior to the left pectoral 
fin [56]. As the weight of each tag must be lower than $2 \%$ of the fish weight, two sizes of PIT tags were used: $23 \mathrm{~mm}$ long and $3.65 \mathrm{~mm}$ diameter, and $12 \mathrm{~mm}$ long and $2.12 \mathrm{~mm}$ diameter (TIRIS model RI181 TRP-WRHP; Texas Instruments). This method shows negligible effects on growth, survival, and behavior of many species [57] and is very common in fish movement studies [58].

Afterwards, fish were transported in aerated water tanks (100 L) and subsequently stabled in two similar groups per fishway (mix of barbel and nase) for acclimation inside cages: groups VS1 and SNBO1 in a pool in the fishway, and groups VS2 and SNBO2 in the river near the fishway (Table 2). Prior to the start of the trials, each group was confined to the initial pool (the most downstream; Figure 2) by two closing mesh areas and a low fishway flow $(50 \mathrm{~L} / \mathrm{s})$, to ensure adaptation and avoid stress or fatigue. Fish were not fed during experiments, although they could access natural food sources drifting into the cages or on the bottom. No fish died during or after the tagging process and trials.

Fish were treated in accordance with the European Union Directive 2010/63/UE on the protection of animals used for scientific purposes, and following the ethical guidelines of Murcia University and the Government of Murcia, under authorization AUF20150077. All efforts were made to minimize stress, and fish were released after the experiments.

\subsection{Trials}

A system of antennas was used in both fishways to detect the movements of the PIT-tagged fish. Four antennas were installed in each fishway at a total head of $1.80 \mathrm{~m}$ (Figure 2), covering the slot in VS and the notch and the orifice in SNBO, with a detection range of $\pm 20 \mathrm{~cm}$ distance from the antenna. Each antenna was connected to a reader (Half Duplex multiplexer reader, ORFID ${ }^{\circledR}$, Portland, Oregon, USA) programmed to send and receive information at $14 \mathrm{~Hz}$ ( $3.5 \mathrm{~Hz}$ or $0.29 \mathrm{~s}$ per antenna).

At the start of a trial, the fishway gate was open, allowing usual operating flow (Table 1), and the closing mesh in the starting pool was removed. Therefore, fish were allowed to ascend volitionally but they could not escape from the fishway due to the presence of the closing meshes in both the lower and upper zones of the experimental area (Figure 2). If a fish reached the uppermost pool, it had two options: remaining there or descending. Two 16-hour trials (from 8:00 to 24:00 h) were attempted in each fishway, one for each fish group; thus, a fish participated in only one trial (Table 2). Prior to trails, other fish that remained in the fishways were removed before releasing experimental individuals from each group.

Water level and temperature were monitored at 30 min intervals (Orpheus Mini, OTT Hydromet $\mathrm{GmbH}$, Kempten, Germany), with small variations observed during the trials $\left(16-19^{\circ} \mathrm{C}\right.$ in the VS group and $14-17^{\circ} \mathrm{C}$ in the $\mathrm{SNBO}$ group). The weather was sunny and cloudless during the experiments.

Table 2. Fish samples.

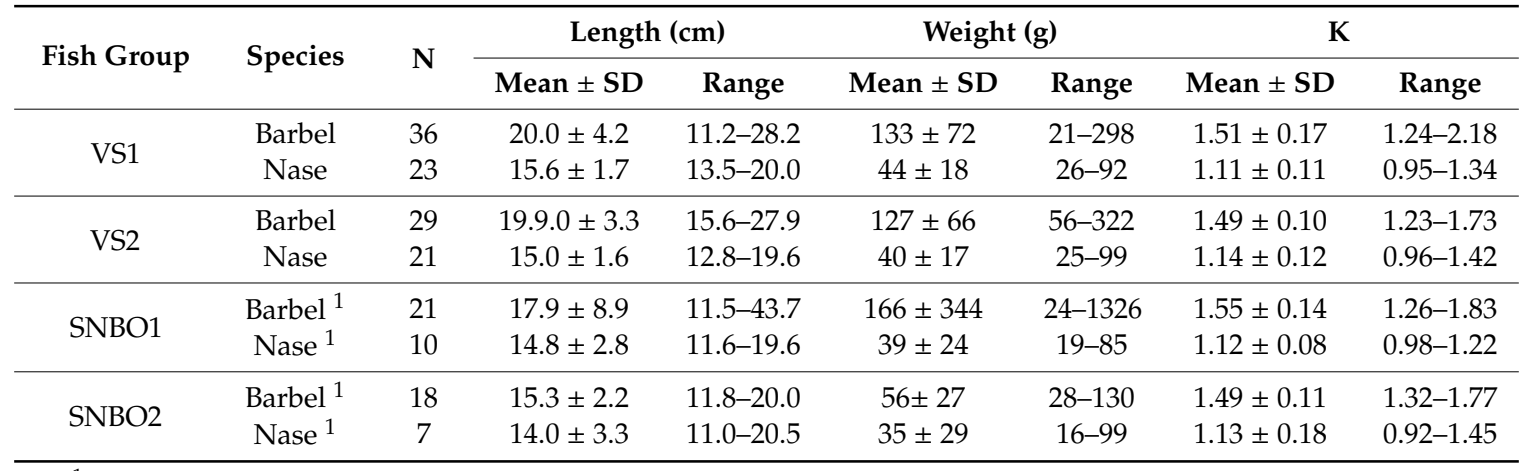

1: Barbels and nases from SNBO group were significantly smaller $(p<0.05)$ than those from VS group. $\mathrm{N}=$ number of fish tagged with PITs; $\mathrm{K}=$ condition factor $(100 \times$ weight/fork length); SD = standard deviation; $\mathrm{VS}=$ vertical slot fishway; $\mathrm{SNBO}=$ submerged notch with bottom orifice fishway; barbel = Luciobarbus sclateri; nase $=$ Pseudochondrostoma polylepis. 


\subsection{Data Analysis}

During each trial, fish were able to make several ascents. To separate the ascent movements from the exploratory ones, we considered a passage attempt as when a fish reached the second antenna (Figure 2, A2). The last detection at antenna 1 (Figure 2, A1) was considered as the starting time of the attempt. The attempts in which the fish reached the most upstream antenna (Figure 2, A4), were deemed successful; otherwise, they were deemed failures.

\subsubsection{Ascent Analysis}

Of those fish that performed attempts, ascent performance was analyzed using two usual metrics [36-38]: (1) ascent success: percentage of fish that reached A4, in relation to the total number of fish that attempted it. It was analyzed by the chi-square test of independence; and (2) transit time: time taken to move from A1 (last detection) to A4 (first detection) in the fastest successful attempt. Cox proportional hazards regression (PROC, PHREG for SAS) with the Schoenfeld and Martingale residuals test for proportionality $[59,60]$ was used to identify differences in transit time by fishway type and species. In addition, survival analysis based on regression models (PROC, LIFEREG, and "Predict" Macro for SAS; [61]) was used to predict the transit time as a function of the significant covariates and the likelihood of ascent in a given time. The best fitting model was selected using Akaike's information criterion (AIC) [62]. Additionally, transit time was also expressed in minutes per meter of ascent height ( $\mathrm{min} / \mathrm{m}$; transit time divided by total water level height ascended), allowing equivalent comparisons to be made between fishways or species. The median was used as the reference value due to the non-normal distribution of the data.

\subsubsection{Motivation Analysis}

Motivation was studied using three specific metrics: (1) attempt percentage: percentage of fish that attempted to ascend in relation to the total number of fish, analyzed using the chi-square test of independence; (2) number of attempts per fish: number of attempts staged by those fish, analyzed via Mann-Whitney test for median comparisons; and (3) attempt rate: proportion of attempts per unit of time, analyzed by Cox proportional hazards regression with Schoenfeld and Martingale test, which stratified the attempts and assessed the influence of fishway type and species. A differentiation between the first attempt (pre-attempt: first attempt in a trial) and the rest of the attempts was considered [38,60].

Water temperature, depth, and fishway discharge were considered invariant during the time of the trials. All statistical analyses were performed using SAS ${ }^{\circledR}$ (Cary, NC, USA) (version 9.4) and Statgraphics Centurion (Statgraphics Technologies, Inc., The Plains, Virginia, USA) (version XVI.II) software.

\section{Results}

Fish groups in each fishway (VS1 vs. VS2, and SNBO1 vs. SNBO2) showed no significant differences in all ascent and motivation metrics ( $p>0.05$ in all cases). Therefore, data for both groups of fish in the same fishway were merged and processed together as a single group. In addition, the possibility of fatigue or learning during the ascent was analyzed by comparing the different attempts, but no pattern was observed to support those hypotheses.

\subsection{Ascent Analysis}

The ascent success in all cases exceeded $80 \%$, with significant differences between the type of fishways for barbel $\left(\chi^{2}=4.735, p=0.032\right)$ but not for nase $\left(\chi^{2}=1.609, p=0.289\right)$ (Table 3). The ascent success had no relation with the fish length for both species ( $p>0.500$ in all cases). Regarding transit time, significant differences were found between types of fishway and species. Barbel needed more time than nase in both fishways ( $p=0.052$ in VS and $p=0.020$ in SNBO), and spent less time in VS than 
in SNBO $(p<0.001)$ (Table 3). However, nase spent similar median time in VS and SNBO $(p=0.687$; Table 3).

Table 3. Results of the used metrics: percentage of attempts, number of attempts, ascent success, and transit time (1.80 $\mathrm{m}$ head).

\begin{tabular}{ccccc}
\hline \multirow{2}{*}{ Metrics } & \multicolumn{2}{c}{ VS (N = 110) } & \multicolumn{2}{c}{ SNBO (N = 56) } \\
\cline { 2 - 5 } & Barbel & Nase & Barbel & Nase \\
\hline Attempt percentage & $(58 / 66) 87.9 \%$ & $(39 / 44) 88.6 \%$ & $(30 / 39) 76.9 \%$ & $(8 / 17) 47.1 \%$ \\
Median number of attempts & $3(1-16)$ & $5(1-12)$ & $2(1-6)$ & $3(1-6)$ \\
Ascent success & $(55 / 58) 94.9 \%$ & $(38 / 39) 94.8 \%$ & $(24 / 30) 80.0 \%$ & $(7 / 8) 87.5 \%$ \\
Median transit time & $(54) 12.5 \mathrm{~min}$ & $(37) 8.0 \mathrm{~min}$ & $(19) 26.3 \mathrm{~min}$ & $(6) 9.3 \mathrm{~min}$ \\
Median transit time per & $6.9 \mathrm{~min} / \mathrm{m}$ & $4.4 \mathrm{~min} / \mathrm{m}$ & $16.6 \mathrm{~min} / \mathrm{m}$ & $5.2 \mathrm{~min} / \mathrm{m}$ \\
meter of height & $(1.3-274.5)$ & $(1.2-342.7)$ & $(4.6-405.3)$ & $(2.1-34.4)$ \\
\hline
\end{tabular}

1: Fish number for the calculus of transit time differs from the total number of successful ascents due to some missing time data in antenna 1 . Note: VS = vertical slot fishway; SNBO = submerged notch with bottom orifice fishway; barbel = Luciobarbus sclateri; nase $=$ Pseudochondrostoma polylepis. The number of fish is indicated in brackets, except for the median number of attempts and median transit time per meter of height, where the range is in brackets.

Overall, fish length showed a significant relationship with transit time $(p=0.024)$. The best fitting predictive model between fish length and transit time was log-logistic survival regression. For barbel, fish length showed an inverse relation with the transit time (the longer fish, the less transit time) in both fishway types $(p<0.05)$ (Figure 3 and Table 4$)$. For nase, while there were no significant differences in VS by fish length $(p=0.981)$, for SNBO the analysis results were significant $(p=0.016)$ but not conclusive, due to the low number of successful ascents (Table 3).

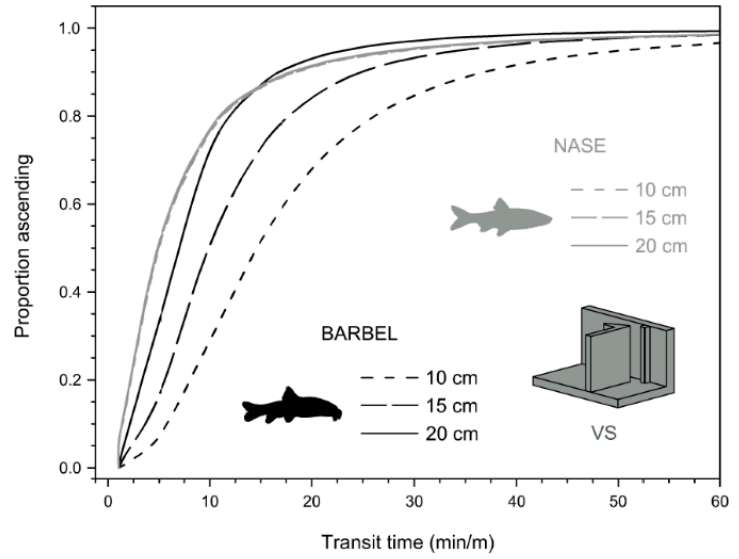

(a)

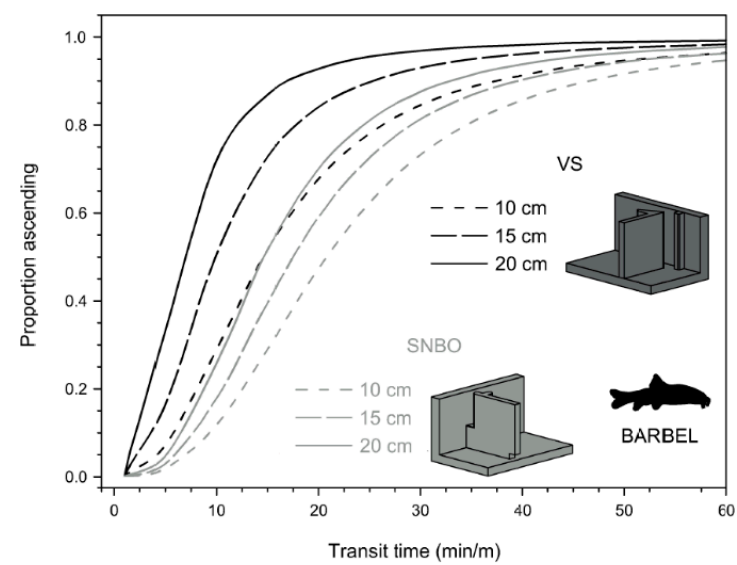

(b)

Figure 3. Predictive log-logistic survival model for the proportion of fish ascending ( $1 \mathrm{~m}$ of height exceeded) at a given transit time as a function of fish species and fork length $(10,15$, and $20 \mathrm{~cm})(\mathbf{a})$, and fishway type and length for barbel (which showed significant differences) (b). Note: VS = vertical Slot fishway; $\mathrm{SNBO}=$ submerged notch with bottom orifice fishway (SNBO); barbel = Luciobarbus sclateri; nase $=$ Pseudochondrostoma polylepis. Nase in SNBO are not included due to the small sample size, which would not achieve a reliable predictive model.

Based on this model (Figure 3 and Table 4), the effect could be expressed approximately as reduction in transit time of $7.5 \%$ for barbel in VS $(\exp (\beta)-1=\exp (-0.078)-1=-0.075)$ and $3.4 \%$ in SNBO per $\mathrm{cm}$ increase in fork length (considering the mean value of all fish). As an example of prediction, it could be said that $50 \%$ of barbel with a fork length of $15 \mathrm{~cm}$ would ascend $1 \mathrm{~m}$ height in $10 \mathrm{~min}$ for VS and in $17 \mathrm{~min}$ for SNBO. However, if the fork length was $10 \mathrm{~cm}$, the transit time would be $14 \mathrm{~min} / \mathrm{m}$ and $21 \mathrm{~min} / \mathrm{m}$, respectively.

Condition factor did not show significant relationships in any case for ascent analysis parameters. 
Table 4. Estimation of the parameters of log-logistic survival model $(\mu=$ regression intercept; $\beta=$ fork length, in cm; $\sigma=$ curve shape of the model) for the proportion of fish ascending at a given transit time as a function of fish length by fishway type (predictive model in Figure 3).

\begin{tabular}{ccccccc}
\hline Barbel & \multicolumn{3}{c}{ VS } & & \multicolumn{3}{c}{ SNBO } & \\
\hline Parameters & Coefficient & SE & $p$ & Coefficient & SE & $p$ \\
\hline Intercept $(\mu)$ & 3.4601 & 0.5425 & $<0.001$ & 3.3816 & 0.3209 & $<0.001$ \\
Length $(\beta)$ & -0.0784 & 0.0268 & 0.0034 & -0.0350 & 0.0155 & 0.0239 \\
Shape $(\sigma)$ & 0.4236 & 0.0487 & & 0.3657 & 0.0725 & \\
\hline Nase & & VS & & & SNBO & \\
\hline Parameters & Coefficient & SE & $p$-value & Coefficient & SE & $p$-value \\
\hline Intercept $(\mu)$ & 1.6243 & 1.7664 & 0.3578 & 5.4887 & 1.6238 & $<0.001$ \\
Length $(\beta)$ & -0.0028 & 0.1161 & 0.9809 & -0.2365 & 0.0979 & 0.0157 \\
Shape $(\sigma)$ & 0.6001 & 0.0882 & & 0.3033 & 0.1063 & \\
\hline
\end{tabular}

Note: SE = coefficient standard error; VS: vertical slot fishway; SNBO = submerged notch with bottom orifice fishway. barbel $=$ Luciobarbus sclateri; nase $=$ Pseudochondrostoma polylepis.

\subsection{Motivation Analysis}

The attempt percentage exceeded $75 \%$ in all cases, except for the nase in SNBO (Table 3). Nase performed a significantly lower number of attempts in SNBO $\left(\chi^{2}=11.987 ; p=0.001\right)$, while barbel showed no differences between fishways $\left(\chi^{2}=2.168 ; p=0.074\right)$ (Table 3). The median number of attempts per fish was higher for barbel in VS than in SNBO ( 3 vs. 2 attempts respectively; $p=0.0165$ ), whereas there were no significant differences for nase ( $5 \mathrm{vs} .3$ attempts; $p=0.168$ ).

Regarding the attempt rate, there were significant differences in relation to the type of fishway $(p<0.001)$ but not between species $(p>0.05)$ for both pre-attempt rate and rate of the rest of attempts (Table 5 and Figure 4). The model fits indicated a significantly lower rate in SNBO than in VS $(\exp (\beta)-$ 1) $\cdot 100=61.4 \%$ and $45.1 \%$ for pre-attempt rate and rate of the rest of attempts, respectively). This means that the likelihood of staging an attempt (hazards ratio $=\exp (\beta)$ ) in SNBO is $38.6 \%$ lower for pre-attempt and $54.9 \%$ lower for other attempts.

Table 5. Estimation of the parameters of the Cox proportional hazards models ( $\beta$ : regression coefficient; HR: hazards ratio $=\exp (\beta)$; SE: standard error) for the attempt rate (pre-attempt and rest of attempts) in relation to the type of fishway and species for the reference factors submerged notch with bottom orifice fishway (SNBO) and nase (Iberian straight-mouth nase).

\begin{tabular}{ccccccc}
\hline \multirow{2}{*}{ Parameters } & \multicolumn{3}{c}{ Pre-Attempt Rate } & \multicolumn{3}{c}{ Rest of Attempts Rate } \\
\cline { 2 - 7 } & $\boldsymbol{\beta} \pm$ SE & $p$-Value & HR & $\beta \pm$ SE & $p$-Value & HR \\
\hline Fishway & $-0.951 \pm 0.189$ & $<0.001$ & 0.386 & $-0.599 \pm 0.149$ & $<0.001$ & 0.549 \\
Species & & 0.595 & & & 0.124 & \\
\hline
\end{tabular}




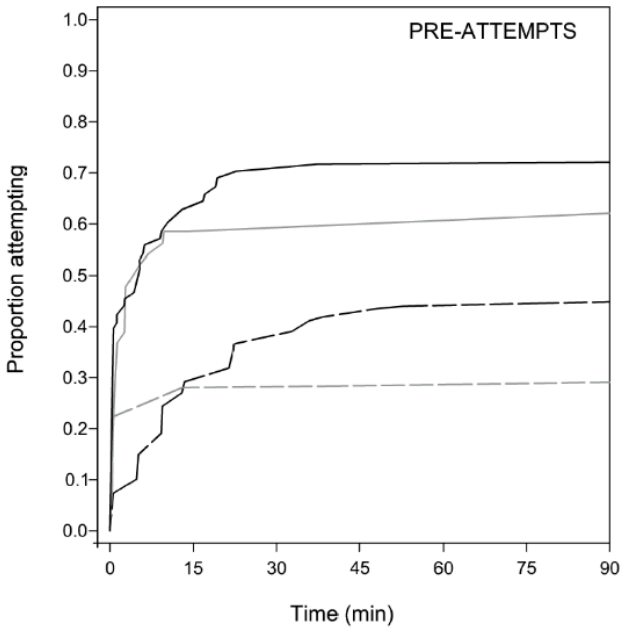

(a)

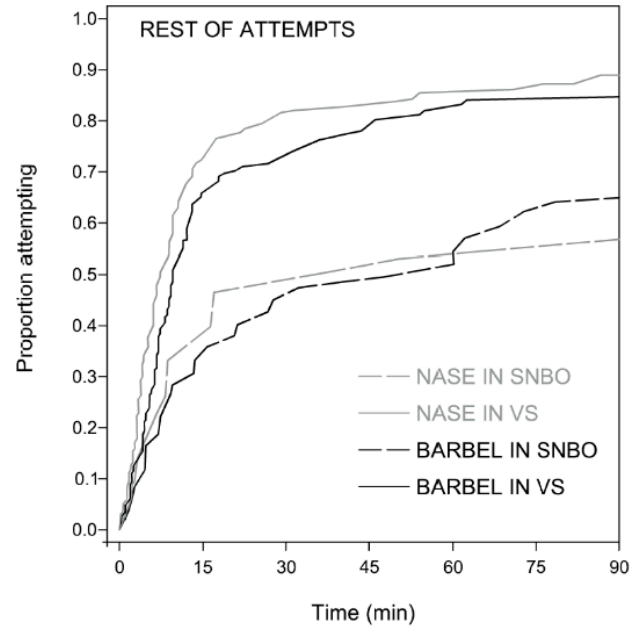

(b)

Figure 4. Kaplan-Meier curves for the proportion of fish attempting to ascend over time. Proportion for the pre-attempt rate (a), and proportion for the rest of the attempts (b).

\section{Discussion}

Most river basins in the Iberian Peninsula have a Mediterranean character, and therefore their native fish communities have evolved and are structured according to these semiarid environments $[20,63]$. These fish species have developed unique life-history strategies, which together with their high degree of rarity and endemicity, determine the high conservation interest presented by these faunal communities [8], as in other regions in the circum-Mediterranean area [12,14]. Longitudinal connectivity disruption is one of the main alterations threatening fish populations $[4,7,18]$, which is probably magnified in environmental scenarios, such as in the Iberian rivers in the Mediterranean area [9].

The present work shows that mitigation measures, such as fishways designed according to criteria of their native fish species, could reduce river fragmentation impacts on these areas. Thus, the passage efficiency is presented for two potamodromous cyprinids, which are sentinel species from semiarid environments with different swimming behavior (Southern Iberian barbel and Iberian straight-mouth nase), through two of the most common pool-type fishways (vertical slot and submerged notch with bottom orifice fishways).

Results reveal that both species easily overcame both types of fishways. Overall, ascent success exceeded $80 \%$ in all trials, with a median transit time lower than $20 \mathrm{~min} / \mathrm{m}$ for barbel and $10 \mathrm{~min} / \mathrm{m}$ for nase, which would not imply an important migratory delay in any case. These values are similar to those for congeners Luciobarbus bocagei and Pseudochondrostoma duriense in the Duero River basin (northern Iberian Peninsula) [36-38]. Other studies for the close relative Barbus barbus in the Swiss Rhone River showed analogous transit time to ours in pool-type fishways [64]. In general, fish size influenced the time needed to overcome the fishway, with longer times for the smaller fish, which is consistent with other fishway evaluations [36-38,65]. Longer fish had more body mass, as well large fins, which are very important as sources of propulsive forces to cross velocity barriers faster $[65,66]$.

Nevertheless, the study reveals significant differences in the variables that define the ascent and the motivation between fishways and species. Nase ascended both types with similar speeds and faster than barbel, meanwhile the latter ascended faster in VS and with higher percentage of success. Both species presented a higher motivation in VS.

Despite the fact that both barbel and nase are rheophilic potamodromous cyprinids [16] and usually coexist in the same river reaches, their swimming behavior is quite different. Barbel is a benthic fish, with a robust body and greater swimming ability than nase for the same fork length $[67,68]$. On the other hand, nase is a water column fish, with a slender body and good swimming and leaping aptitudes, which allow them to easily overcome obstacles [36]. 
Differences between our target species could be related to the date of the trials in relation to the reproductive periods of both [19]. Nase fish usually start spawning migration earlier than barbel, with the migratory peak in May, whereas barbel fish start at the beginning of June for the Segura River Basin [69]. Therefore, nase fish were expected to be more active than barbel during trials. However, ascent motivation was similar in both species, except for nase fish in SNBO, which showed lower attempt percentage. The upper water origin for the nase sample in SNBO compared to VS could partly explain the lower motivation for nase group. Colder water temperatures in upper parts of the basin could delay the maturation, and therefore the motivation, compared to the middle part in the main stream, and also the change of water quality from the capture area to the experimental site could influence fish behavior [37]. Moreover, although the difference between SNBO and VS in the experimental fish size was very small, individuals from the first type were significantly smaller, which could also have had an effect on fish motivation. All of our experimental individuals were mature fish [19], but in the case of nase fish, the first size of maturity was very close to the average size of the experimental specimens, which was more obvious in SNBO individuals.

Alexandre et al. [70] observed differences in swimming ability for Luciobarbus bocagei population depending on the river stretch of origin, which could be related to their genetic origin, but also to the habitat drivers from each population. Results from our study also showed slight differences in metrics, which could be explained by the origin of the populations and of each target species. Although nase has been completely adapted to the Segura River Basin since its colonization [19], it originally inhabits stretches of high-moderate velocity in their native source from the Tagus River, which are very different from the slow waters of the Segura River in the studied fluvial sector. Compared to barbel, it is best adapted to running waters, which could explain the faster transit times observed in the present study.

Although the hydraulic design parameters of both fishways were within the usual recommendations for cyprinids [24,32], some slight differences were found between them regarding the volumetric energy dissipation and water velocity. Changes in headwater or tailwater levels modify the hydraulic conditions in the entrance from the ones defined during the design process, causing non-uniform (backwater or drawdown) profiles [33]. During trials, the SNBO presented a more evident backwater profile, where the downstream pools, including the starting pools and the pools between $\mathrm{A} 1$ and $\mathrm{A} 2$, were more submerged (water drops $<0.15 \mathrm{~m}$ ) than the other pools. This produced lower water velocity in the notches and orifices, and lower volumetric energy dissipation in pools (less than $1 \mathrm{~m} / \mathrm{s}$ and $100 \mathrm{~W} / \mathrm{m}^{3}$ ), which could have reduced the motivation due to the relationship with velocity in the notches [60,71,72], which would have increased the transit time. Larinier et al. [73] recommends a speed higher than $1 \mathrm{~m} / \mathrm{s}$ in the notches and slots for most species, and in the order of $2 \mathrm{~m} / \mathrm{s}$ to $2.4 \mathrm{~m} / \mathrm{s}$ for large rheophilic fish.

Therefore, fishway design projects for upstream migrating fish, specifically for potamodromous cyprinids in semiarid environments such as the Segura River, may provide an opportunity to develop safe, timely, and effective fish passage structures. Results obtained in this field study reveal that both fishway types, if correctly designed and constructed, offer interesting alternatives to mitigate the longitudinal connectivity problems for two sentinel cyprinids from those rivers in semiarid environments. However, further research is necessary to improve the knowledge of the relationships between the behavior and swimming ability of different fish species in the different fishway types and hydraulic scenarios. In fact, a complete and exhaustive fish-based monitoring assessment of the effectiveness of fishways should be an essential part of any project, in order to restore the longitudinal connectivity.

Author Contributions: All authors have contributed substantially to the manuscript development. F.J.S.-R., M.T., and F.J.O.-P. conceptualized, supervised, and administered the project. F.J.B.-C. and F.J.S.-R. designed the applied methodology. F.J.B.-C., L.F.-C., and A.S.-P. conducted the experiments and data collection. F.J.B.-C., A.G.-V., and L.F.-C. analyzed the data. J.V.-C. performed the visualization of this work. F.J.S.-R. wrote the original draft, which was revised by the other authors.

Funding: This research was funded by LIFE+ Segura Riverlink, project LIFE12 ENV/1140. Ana Sánchez-Pérez's contribution was financed by a Ph.D. grant from the Spanish Ministry of Science and Education FPU14/03994. 
Ana García-Vega's contribution was financed by a Ph.D. grant from the University of Valladolid PIF- UVa 2017. Jorge Valbuena-Castro's contribution was financed by a public Ph.D. grant from Junta de Castilla y León and European Social Fund PIF-2017.

Acknowledgments: The authors would like to thank to Agrarian Technological Institute (ITAGRA.CT) for its technical and human support.

Conflicts of Interest: The authors declare no conflict of interest. The funders had no role in the design of the study; in the collection, analyses, or interpretation of data; in the writing of the manuscript, or in the decision to publish the results.

\section{References}

1. Gasith, A.; Resh, V.H. Streams in Mediterranean climate regions: Abiotic influences and biotic responses to predictable seasonal events. Annu. Rev. Ecol. Syst. 1999, 30, 51-81. [CrossRef]

2. Seager, R.; Osborn, T.J.; Kushnir, Y.; Simpson, I.R.; Nakamura, J.; Liu, H. Climate variability and change of mediterranean-type climates. J. Clim. 2019, 32, 2887-2915. [CrossRef]

3. Grill, G.; Lehner, B.; Lumsdon, A.E.; MacDonald, G.K.; Zarfl, C.; Reidy Liermann, C. An index-based framework for assessing patterns and trends in river fragmentation and flow regulation by global dams at multiple scales. Environ. Res. Lett. 2015, 10, 015001. [CrossRef]

4. Smith, K.G.; Barrios, V.; Darwall, W.R.T.; Numa, C. The Status and Distribution of Freshwater Biodiversity in the Eastern Mediterranean; IUCN: Gran, Switzerland, 2014; ISBN 9782831716992.

5. Lucas, M.C.; Baras, E.; Thom, T.J.; Duncan, A.; Slavík, O. Migration of Freshwater Fishes; Blackwell Science: Oxford, UK, 2001; ISBN 0632057548.

6. Nilsson, C.; Reidy, C.A.; Dynesius, M.; Revenga, C. Fragmentation and flow regulation of the world's large river systems. Science 2005, 308, 405-408. [CrossRef]

7. Coad, B. Endemicity in the freshwater fishes of Iran. Iran. J. Anim. Biosyst. 2006, 1, 1-13.

8. Maceda-Veiga, A. Towards the conservation of freshwater fish: Iberian Rivers as an example of threats and management practices. Rev. Fish Biol. Fish. 2013, 23, 1-22. [CrossRef]

9. Hermoso, V.; Clavero, M. Threatening processes and conservation management of endemic freshwater fish in the Mediterranean basin: A review. Mar. Freshw. Res. 2011, 62, 244-254. [CrossRef]

10. Vörösmarty, C.J.; Green, P.; Salisbury, J.; Lammers, R.B. Global Water Resources: Vulnerability from Climate Change and Population Growth. Science 2000, 289, 284-289. [CrossRef]

11. Solomon, S.; Qin, D.; Manning, M.; Marquis, M.; Averty, K.; Tignor, M.M.B.; Miller, H.L.; Chen, Z. Contribution of Working Group I to the Fourth Assessment Report of the Intergovernmental Panel on Climate Change; Cambridge University Press: Cambridge, UK, 2007.

12. Clavero, M.; Blanco-Garrido, F.; Prenda, J. Fish fauna in Iberian Mediterranean river basins: Biodiversity, introduced species and damming impacts. Aquat. Conserv. Mar. Freshw. Ecosyst. 2004, 14, 575-585. [CrossRef]

13. Kottelat, M.; Freyhof, J. Handbook of European Freshwater Fishes; Publications Kottelat: Cornol, Switzerland; Berlin, Germany, 2007; ISBN 978-2-8399-0298-4.

14. Jouladeh-Roudbar, A.; Vatandoust, S.; Eagderi, S.; Jafari-Kenari, S.; Mousavi-Sabet, H. Freshwater fishes of Iran; an updated checklist. Aquac. Aquar. Conserv. Legis. 2015, 8, 855-909.

15. Froese, R.; Pauly, D. FishBase. Available online: www.fishbase.org (accessed on 26 September 2019).

16. Doadrio, I. Atlas y Libro Rojo de los Peces Continentales de España; Dirección General de Conservación de la Naturaleza; Museo Nacional de Ciencias Naturales: Madrid, Spain, 2002; ISBN 84-8014-313-4.

17. Collares-Pereira, M.; Martins, M.; Pires, A.; Geraldes, A.; Coelho, M. Feeding behaviour of Barbus bocagei assessed under a spatio-temporal approach. Folia Zool. 1996, 45, 65-76.

18. Doadrio, I.; Perea, S.; Garzón-Heydt, P.; González, J.L. Ictiofauna Continental Española: Bases Para su Seguimiento; Ministerio de Medio Ambiente y Medio Rural y Marino: Madrid, Spain, 2011; ISBN 978-84-491-1158-7.

19. Torralva, M.M.; Oliva-Paterna, F.J. First record of Chondrostoma polylepis Steindachner, 1865 (Ostariophysi, Cyprinidae) in the basin of the Segura River, SE of Spain. Limnetica 1997, 13, 1-3.

20. Encina, L.; Rodriguez, A.; Granado-Lorencio, C. The Iberian ichthyofauna: Ecological contributions. Limnetica 2006, 25, 349-368.

21. Pringle, C. What is hydrologic connectivity and why is it ecologically important? Hydrol. Process. 2003, 17, 2685-2689. [CrossRef] 
22. Vannote, R.L.; Minshall, G.W.; Cummins, K.W.; Sedell, J.R.; Cushing, C.E. The River Continuum Concept. Can. J. Fish. Aquat. Sci. 1980, 37, 130-137. [CrossRef]

23. Clay, C.H. Design of Fishways and Other Fish Facilities, 2nd ed.; CRC Press: Boca Raton, FL, USA, 1994; ISBN 1566701112.

24. Food and Agriculture Organization of the United Nations; Deutscher Verband für Wasserwirtschaft und Kulturbau e. V. Fish Passes: Design, Dimensions and Monitoring; FAO: Rome, Italy, 2002; ISBN 9251048940.

25. Lynch, H.A. Report to the Government of Iraq on Fishways at Dams on the Tigris and Euphrates Rivers; Report No 526; FAO: Rome, Italy, 1956.

26. Elvira, B.; Nicola, G.G.; Almodóvar, A. Impacto de las Obras Hidráulicas en la Ictiofauna: Dispositivos de Paso Para Peces en las Presas de España; Organismo Autónomo Parques Nacionales: Madrid, Spain, 1998; ISBN 8480142545.

27. Verep, B.; Küçükali, S.; Turan, D.; Alp, A. A Critical Analysis of Existing Fish A Critical Analysis of Existing Fish Pass Structures at Small Hydropower Plants in Turkey. In Proceedings of the International Conference on Engineering and Ecohydrology for Fish Passage, Amherst, MA, USA, 22 June 2016; p. 53.

28. Pervin, A. Fish passages from past to future in Turkey. In Proceedings of the International Conference on Engineering and Ecohydrology for Fish Passage, Corvallis, OR, USA, 19 June 2017; p. 49.

29. Comoglio, C.; (Politecnico di Torino, Turin, Italy). Personal communication, 2019.

30. Mimeche, F.; (Université de M’Sila, M’Sila, Algeria). Personal communication, 2019.

31. Koutrakis, E.T.; (Fisheries Research Institute, National Agricultural Research Foundation, Kavala, Greece). Personal communication, 2019.

32. Larinier, M. Pool fishways, pre-barrages and natural bypass channels. Bull. Français Pêche Piscic. 2002, 364, 54-82. [CrossRef]

33. Fuentes-Pérez, J.F.; García-Vega, A.; Sanz-Ronda, F.J.; Martínez de Azagra Paredes, A. Villemonte's approach: Validation of a general method for modeling uniform and non-uniform performance in stepped fishways. Knowl. Manag. Aquat. Ecosyst. 2017, 418, 11. [CrossRef]

34. Silva, A.T.; Ferreira, M.T.; Santos, J.M.; Pinheiro, A.N.; Melo, J.F.; Bochechas, J.H. Development of a pool-type fishway facility for Iberian cyprinids. In Proceedings of the International Symposium on Ecohydraulics, Madrid, Spain, 12 September 2004; pp. 924-947.

35. Noonan, M.J.; Grant, J.W.A.; Jackson, C.D. A quantitative assessment of fish passage efficiency. Fish Fish. 2012, 13, 450-464. [CrossRef]

36. Sanz-Ronda, F.J.; Bravo-Córdoba, F.J.; Fuentes-Pérez, J.F.; Castro-Santos, T. Ascent ability of brown trout, Salmo trutta, and two Iberian cyprinids- Iberian barbel, Luciobarbus bocagei, and northern straight-mouth nase, Pseudochondrostoma duriense- in a vertical slot fishway. Knowl. Manag. Aquat. Ecosyst. 2016, 417, 10. [CrossRef]

37. Bravo-Córdoba, F.J.; Sanz-Ronda, F.J.; Ruiz-Legazpi, J.; Fernandes Celestino, L.; Makrakis, S. Fishway with two entrance branches: Understanding its performance for potamodromous Mediterranean barbels. Fish. Manag. Ecol. 2018, 25, 12-21. [CrossRef]

38. Bravo-Córdoba, F.J.; Sanz-Ronda, F.J.; Ruiz-Legazpi, J.; Valbuena-Castro, J.; Makrakis, S. Vertical slot versus submerged notch with bottom orifice: Looking for the best technical fishway type for Mediterranean barbels. Ecol. Eng. 2018, 122, 120-125. [CrossRef]

39. Branco, P.; Amaral, S.D.; Ferreira, M.T.; Santos, J.M. Do small barriers affect the movement of freshwater fish by increasing residency? Sci. Total Environ. 2017, 581-582, 486-494. [CrossRef] [PubMed]

40. Sanz-Ronda, F.J.; Fuentes-Pérez, J.F.; García-Vega, A. Escala de artesas en el azud Soto Damián en el río Segura (Abarán, Murcia) LIFE12 ENV/ES/1140 RIVERLINK (Applied Ecohydraulics Group, Palencia, Spain). Available online: https://www.chsegura.es/chs/cuenca/segurariverlink/riverlink/ (accessed on 28 September 2017).

41. Sanz-Ronda, F.J.; Fuentes-Pérez, J.F.; García-Vega, A. Escala de artesas en el azud Elevación Zona 1 Postrasvase en el río Segura (Calasparra, Murcia) LIFE12 ENV/ES/1140 RIVERLINK (Applied Ecohydraulics Group, Palencia, Spain). Available online: https://www.chsegura.es/chs/cuenca/segurariverlink/riverlink/ (accessed on 28 September 2017).

42. James, R.S.; Johnston, I.A. Scaling of muscle performance during escape responses in the fish Myoxocephalus scorpius L. J. Exp. Biol. 1998, 201, 913-923. [PubMed] 
43. Plaut, I. Does pregnancy affect swimming performance of female Mosquitofish, Gambusia affinis? Funct. Ecol. 2002, 16, 290-295. [CrossRef]

44. Clough, S.; Lee-Elliot, I.; Turnpenny, A.; Holden, S.; Hinks, C. Swimming Speeds in Fish: Phase 2. Technical Report W2-049/TR1; Environment Agency: Bristol, UK, 2004.

45. Pedersen, L.F.; Koed, A.; Malte, H. Swimming performance of wild and F1-hatchery-reared Atlantic salmon (Salmo salar) and brown trout (Salmo trutta) smolts. Ecol. Freshw. Fish 2008, 17, 425-431. [CrossRef]

46. Castro-Santos, T.; Cotel, A.; Webb, P. Fishway Evaluations for Better Bioengineering: An Integrative Approach. In Challenges for Diadromous Fishes in a Dynamic Global Environment, Proceedings of the American Fisheries Society Symposium, Halifax, NS, Canada, 18 June 2007; Haro, A., Smith, K.G., Rulifson, R.A., Moffitt, C.M., Klauda, R.J., Dadswell, M.J., Cunjak, R.A., Cooper, J.E., Beal, K.L., Avery, T.S., Eds.; American Fisheries Society: Bethesda, MD, USA, 2009; Volume 69, pp. 557-575.

47. Castro-Santos, T.; Haro, A. Fish guidance and passage at barriers. In An Eco-Ethological Perspective; Domeneci, P., Kapoor, B.G., Eds.; Science Publishers: Enfield, NH, USA, 2010; pp. 62-89.

48. Cooke, S.J.; Hinch, S.G. Improving the reliability of fishway attraction and passage efficiency estimates to inform fishway engineering, science, and practice. Ecol. Eng. 2013, 58, 123-132. [CrossRef]

49. Romão, F.; Branco, P.; Quaresma, A.L.; Amaral, S.D.; Pinheiro, A.N. Effectiveness of a multi-slot vertical slot fishway versus a standard vertical slot fishway for potamodromous cyprinids. Hydrobiologia 2018, 816, 153-163. [CrossRef]

50. Grindlay, A.L.; Zamorano, M.; Rodríguez, M.I.; Molero, E.; Urrea, M.A. Implementation of the European Water Framework Directive: Integration of hydrological and regional planning at the Segura River Basin, southeast Spain. Land Use Policy 2011, 28, 242-256. [CrossRef]

51. Illies, J.; Botoseanu, L. Problèmes et méthodes de la classification et de la-zonation écologique des eaux courantes, considérées surtout-du point de vue faunistique. Mitt. Int. Ver. fuer Theor. Amgewandte Limnol. 1963, 12, 1-57. [CrossRef]

52. Rosgen, D.L.; Silvey, H.L. Applied River Morphology; Wildland Hydrology Books: Fort Collins, CO, USA, 1996.

53. Oliva-Paterna, F.J.; Verdiell-Cubedo, D.; Ruiz-Navarro, A.; Torralva, M. La ictiofauna continental de la Cuenca del río Segura (SE Península Ibérica): Décadas después de Mas (1986). An. Biol. 2014, 6, 37-45.

54. Oliva-Paterna, F.J.; Lafuente, E.; Olivo del Amo, R.; Sanz-Ronda, F.J.; Sánchez-Balibrea, J.; Diaz-García, R.; Torralva, M. LIFE+ Segura-Riverlink: A green infrastructure approach to restore the longitudinal connectivity. Fish. Mediterr. Environ. 2016, 7,1-3. [CrossRef]

55. Rajaratnam, N.; Van der Vinne, G.; Katopodis, C. Hydraulics of vertical slot fishways. J. Hydraul. Eng. 1986, 112, 909-927. [CrossRef]

56. Castro-Santos, T.; Vono, V. Posthandling survival and PIT tag retention by alewives- A comparison of gastric and surgical implants. N. Am. J. Fish. Manag. 2013, 33, 790-794. [CrossRef]

57. Ostrand, K.G.; Zydlewski, G.B.; Gale, W.L.; Zydlewski, J.D. Long term retention, survival, growth, and physiological indicators of salmonids marked with passive integrated transponder tags. In Advances in Fish Tagging and Marking Technology; McKenzie, J., Parsons, B., Seitz, A., Kopf, R.K., Mesa, M.G., Phelps, Q., Eds.; American Fisheries Society: Bethesda, MD, USA, 2012; pp. 135-145.

58. Cooke, S.J.; Midwood, J.D.; Thiem, J.D.; Klimley, P.; Lucas, M.C.; Thorstad, E.B.; Eiler, J.; Holbrook, C.; Ebner, B.C. Tracking animals in freshwater with electronic tags: Past, present and future. Anim. Biotelemetry 2013, 1, 5. [CrossRef]

59. Enders, E.C.; Castro-Santos, T.; Lacey, R.W.J. The effects of horizontally and vertically oriented baffles on flow structure and ascent performance of upstream-migrating fish. J. Ecohydraulics 2017, 2, 38-52. [CrossRef]

60. Goerig, E.; Castro-Santos, T. Is motivation important to brook trout passage through culverts? Can. J. Fish. Aquat. Sci. 2017, 74, 885-893. [CrossRef]

61. Allison, P.D. Survival Analysis Using SAS: A Practical Guide; SAS Institute: Cary, NC, USA, 2010; ISBN 978-1-59994-640-5.

62. Akaike, H. A new look at the statistical model Identification. IEEE Trans. Automat. Contr. 1974, 19, 716-723. [CrossRef]

63. Alexandre, C.M.; Ferreira, M.T.; Almeida, P.R. Fish assemblages in non-regulated and regulated rivers from permanent and temporary Iberian systems. River Res. Appl. 2013, 29, 1042-1058. [CrossRef] 
64. Grimardias, D. Evaluation de l'efficacité des dispositifs de franchissement des barrages via la méthode télémetrique (module 2). In Proceedings of the Programme INTERREG IV A France-Suisse, Bonneville, France, 17 June 2015.

65. Assumpção, L.; Makrakis, M.C.; Makrakis, S.; Wagner, R.L.; Da Silva, P.S.; de Lima, A.F.; Kashiwaqui, E.A.L. The use of morphometric analysis to predict the swimming efficiency of two Neotropical long-distance migratory species in fish passage. Neotrop. Ichthyol. 2012, 10, 797-804. [CrossRef]

66. Videler, J.J.; Wardle, C.S. Fish swimming stride by stride: Speed limits and endurance. Rev. Fish Biol. Fish. 1991, 1, 23-40. [CrossRef]

67. Sanz-Ronda, F.J.; Ruiz-Legazpi, J.; Bravo-Córdoba, F.J.; Makrakis, S.; Castro-Santos, T. Sprinting performance of two Iberian fish: Luciobarbus bocagei and Pseudochondrostoma duriense in an open channel flume. Ecol. Eng. 2015, 83, 61-70. [CrossRef]

68. Ruiz-Legazpi, J.; Sanz-Ronda, F.J.; Bravo-Córdoba, F.J.; Fuentes-Pérez, J.F.; Castro-Santos, T. Influencia de factores ambientales y biométricos en la capacidad de nado del barbo ibérico (Luciobarbus bocagei Steindachner, 1864), un ciprínido potamódromo endémico de la Península Ibérica. Limnetica 2018, 37, 251-265.

69. Oliva-Paterna, F.J.; Sánchez-Pérez, A.; Zamora-Marín, J.M.; Zamora-López, A.; Amat-Trigo, F.; Guillén-Beltrán, A.; Bravo-Córdoba, F.J.; Sanz-Ronda, F.J.; Lafuente, E.; Torralva, M. Use of fish passes in a highly regulated Mediterranean river: Final insights and lesson learned in the LIFE+ Segura-Riverlink. In Proceedings of the VII Iberian Congress on Ichthyology, Faro, Algarve, Portugal, 13 June 2018; p. 17.

70. Alexandre, C.M.; Quintella, B.R.; Ferreira, A.F.; Romão, F.A.; Almeida, P.R. Swimming performance and ecomorphology of the Iberian barbel Luciobarbus bocagei (Steindachner, 1864) on permanent and temporary rivers. Ecol. Freshw. Fish 2014, 23, 244-258. [CrossRef]

71. Santos, J.M.; Silva, A.; Katopodis, C.; Pinheiro, P.; Pinheiro, A.; Bochechas, J.; Ferreira, M.T. Ecohydraulics of pool-type fishways: Getting past the barriers. Ecol. Eng. 2012, 48, 38-50. [CrossRef]

72. Fuentes-Pérez, J.F.; Sanz-Ronda, F.J.; Martínez de Azagra, A.; García-Vega, A. Non-uniform hydraulic behavior of pool-weir fishways: A tool to optimize its design and performance. Ecol. Eng. 2016, 86, 5-12. [CrossRef]

73. Larinier, M.; Travade, F.; Porcher, J.P. Fishways: Biological basis, design criteria and monitoring. Bull. Français Pêche Piscic. 2002, 364, 208. 